\title{
Analisis Kemampuan Representasi Matematis Mahasiswa pada Mata Kuliah Geometri Transformasi Berdasarkan Latar Belakang Pendidikan Menengah
}

\author{
Karunia Eka Lestari11, Mokhammad Ridwan Yudhanegara ${ }^{2}$ \\ 1,2 Program Studi Pendidikan Matematika Fakultas Keguruan dan Ilmu Pendidikan Universitas \\ Singaperbangsa Karawang \\ Jl. H. S Ronggowaluyo Telukjambe Timur Karawang, Jawa Barat \\ Email:karunia@staff.unsika.ac.id, mridwan.yudhanegara@staff.unsika.ac.id
}

\begin{abstract}
ABSTRAK
Penelitian ini memfokuskan pada analisis kemampuan representasi matematis mahasiswa dalam mata kuliah Geometri Transformasi berdasarkan latar belakang pendidikan menengah. Latar belakang pendidikan yang diamati dikelompokkan menjadi empat kelompok yaitu SMA-IPA, SMA-IPS, SMK, dan MA. Pendekatan yang digunakan yaitu pendekatan kuantitatif dengan metode expost facto dan desain kausal-komparatif. Sampel dalam penelitian ini adalah seluruh mahasiswa semester V tahun ajaran 2015-2016. Berdasarkan uji Kruskal-Walis $H$ diperoleh nilai signifikansi untuk keempat kelompok adalah 0,168. Hal ini menunjukkan bahwa tidak terdapat perbedaan kemampuan representasi matematis berdasarkan mahasiswa pada mata kuliah Geometri Transformasi berdasarkan latar belakang pendidikan menengah.
\end{abstract}

Kata kunci: representasi matematis, latar Belakang pendidikan menengah.

\begin{abstract}
This study focus on the student mathematical representation in Transformation Geometry courses based on secondary educational background. The secondary educational background was observed on four groups; SMA-IPA, SMA-IPS, SMK, and MA. This study used quantitative approach with ex post facto methods and causal-comparative design. The sample of this study were all of student at 5th semester in 2015-2016 of academic year. Based on Kruskal-Wallis H test obtained significance value for the four groups was 0.168. It show that there is no statistically difference between the four groups in mathematical representation of Transformation Geometry courses based on secondary educational background.
\end{abstract}

Keywords: mathematical representation, secondary educational background.

\section{Pendahuluan}

Pada struktur kurikulum Program Studi Pendidikan Matematika Fakultas Keguruan dan Ilmu Pendidikan (FKIP UNSIKA), mata kuliah Geometri Transformasi merupakan salah satu mata kuliah yang tergolong ke dalam Mata Kuliah Keahlian Program Studi dengan bobot 3 sks. Mata kuliah ini membahas tentang transformasi pada bidang geometri Euclid seperti transformasi pencerminan, translasi, translasi geser, rotasi, dilatasi, isometri.

Materi-materi tersebut menuntut mahasiswa untuk dapat menyajikan kembali notasi, simbol, tabel, gambar, grafik, diagram, persamaan atau ekspresi matematis lainnya ke dalam bentuk lain. Dengan demikian, kemampuan representasi matematis merupakan kemampuan yang sangat menunjang keberhasilan mahasiswa pada mata kuliah ini.

Namun sangat disayangkan, berdasarkan hasil analisis yang peneliti lakukan pada mahasiswa semester V tahun ajaran 2015-2016 Program Studi Pendidikan Matematika menunjukkan bahwa mahasiswa mengalami kesulitan dalam representasi matematis terutama pada hal yang berkaitan dengan: (1) membuat gambar bangun geometri untuk memperjelas masalah dan memfasilitasi penyelesaian; (2) melakukan penyelesaian masalah dengan melibatkan ekspresi matematis; (3) membuat situasi masalah berdasarkan 
data atau representasi yang diberikan; dan (4) menulis interpretasi dari suatu representasi. Hal tersebut menunjukkan bahwa penguasaan mahasiswa dalam merepresentasikan gambar, teks tertulis, persamaan atau ekspresi matematis masih lemah.

Salah satu faktor yang diduga berpengaruh terhadap penguasaan kemampuan representasi matematis pada mahasiswa adalah latar belakang pendidikan sekolah menengah. Diketahui sebelumnya bahwa latar belakang pendidikan sekolah menengah mahasiswa Prodi Pendidikan Matematika FKIP UNSIKA sangat heterogen, yaitu berlatar belakang pendidikan dari Sekolah Menengah Atas (SMA), Sekolah Menengah Kejuruan (SMK), dan Madrasah Aliyah (MA). Melalui penelitian ini peneliti bermaksud untuk melakukan perunutan kembali guna menganalisis kemampuan representasi matematis mahasiswa pada mata kuliah Geometri Transformasi berdasarkan latar belakang pendidikan menengah.

\section{Metode Penelitian}

\subsection{Rancangan Penelitian}

Pendekatan penelitian ini yang digunakan adalah kuantitatif dengan metode expost facto. Metode expost facto yaitu metode penemuan empiris yang dilakukan secara sistematis, peneliti tidak melakukan kontrol terhadap variabel-variabel bebas karena manifestasinya sudah terjadi atau variabel-variabel tersebut secara inheren tidak dapat dimanipulasi (Kerlinger, 1973). Pada penelitan ini, keterikatan antar kemampuan representasi matematis dan latar belakang pendidikan menengah, sudah terjadi secara alami, dan peneliti dengan setting tersebut ingin melacak kembali apa yang menjadi faktor penyebabnya. Dengan demikian, peneliti dalam penelitian ini tidak melakukan manipulasi berupa treatment dalam pembelajaran, melainkan melakukan analisis hubungan dengan merunut kembali peristiwa yang telah terjadi. Proses perunutan tersebut dilakukan dengan mengumpulkan data mengenai latar belakang pendidikan menengah mahasiswa.

Desain penelitian yang digunakan adalah the basic causal-comparatif design, Fraenkel et al. (2012) mengilustrasikan desain seperti pada Tabel 1.

Tabel 1. Desain Penelitian Kausal-komparatif

\begin{tabular}{|c|c|c|}
\hline Grup & $\begin{array}{c}\text { Latar Belakang Sekolah } \\
\text { Menengah } \\
\text { (Independent variable) }\end{array}$ & $\begin{array}{c}\text { Kemampuan Representasi } \\
\text { Matematis } \\
\text { (Dependent variable) }\end{array}$ \\
\hline I & Characteristic 1 (C1) & Measurement (O) \\
\hline II & Characteristic 2 (C2) & Measurement (O) \\
\hline III & Characteristic 3 (C3) & Measurement (O) \\
\hline IV & Characteristic 4 (C4) & Measurement (O) \\
\hline
\end{tabular}

Keterangan: C1 = Lulusan SMA-IPA, C2 = Lulusan SMA-IPS, C3 = Lulusan SMK, C4 = Lulusan $\mathrm{MA}, \mathrm{O}=$ Tes Kemampuan Representasi Matematis.

Populasi dalam penelitian ini adalah seluruh mahasiswa semester V tahun ajaran 2015-2016, Program Studi Pendidikan Matematika FKIP UNSIKA yang mengontrak mata kuliah Geometri Transformasi. Adapun teknik sampling yang digunakan adalah sampling jenuh, dimana seluruh anggota populasi dijadikan sebagai sampel dalam penelitian.

Instrumen yang digunakan dalam penelitian adalah instrumen tes. Instrumen tes terdiri atas seperangkat soal UTS dan UAS yang memuat indikator kemampuan representasi matematis. Tipe soal yang digunakan dalam instrumen tes berbentuk soal uraian (essay) dengan penskoran seperti pada Tabel 2. 
Tabel 2. Kriteria Penskoran Kemampuan Representasi Matematis

\begin{tabular}{|l|c|c|c|}
\hline \multirow{2}{*}{ Indikator Kemampuan Representasi Matematis } & $\begin{array}{c}\text { Tidak } \\
\text { Menjawab }\end{array}$ & $\begin{array}{c}\text { Jawaban Salah } \\
\text { atau Kurang } \\
\text { tepat }\end{array}$ & $\begin{array}{c}\text { Menjawab } \\
\text { dengan tepat }\end{array}$ \\
\cline { 3 - 4 } $\begin{array}{l}\text { Representasi gambar, yaitu kemampuan dalam } \\
\text { membuat gambar pola-pola geometri }\end{array}$ & & & \\
\cline { 1 - 1 } $\begin{array}{l}\text { Representasi persamaan atau ekspresi matematis, } \\
\text { yaitu membuat gambar persamaan atau model } \\
\text { matematis dari representasi lain yang diberikan. }\end{array}$ & Skor $=0$ & $0<$ Skor $<99$ & Skor $=100$ \\
\hline
\end{tabular}

\subsection{Teknik Analisis Data}

Guna menjawab rumusan masalah dan memecahkan masalah dalam penelitian, maka data yang diperoleh dianalisis menggunakan teknik-teknik tertentu sehingga diperoleh suatu kesimpulan dan temuan hasil penelitian. Alur teknik analisis data disajikan pada Gambar 1.

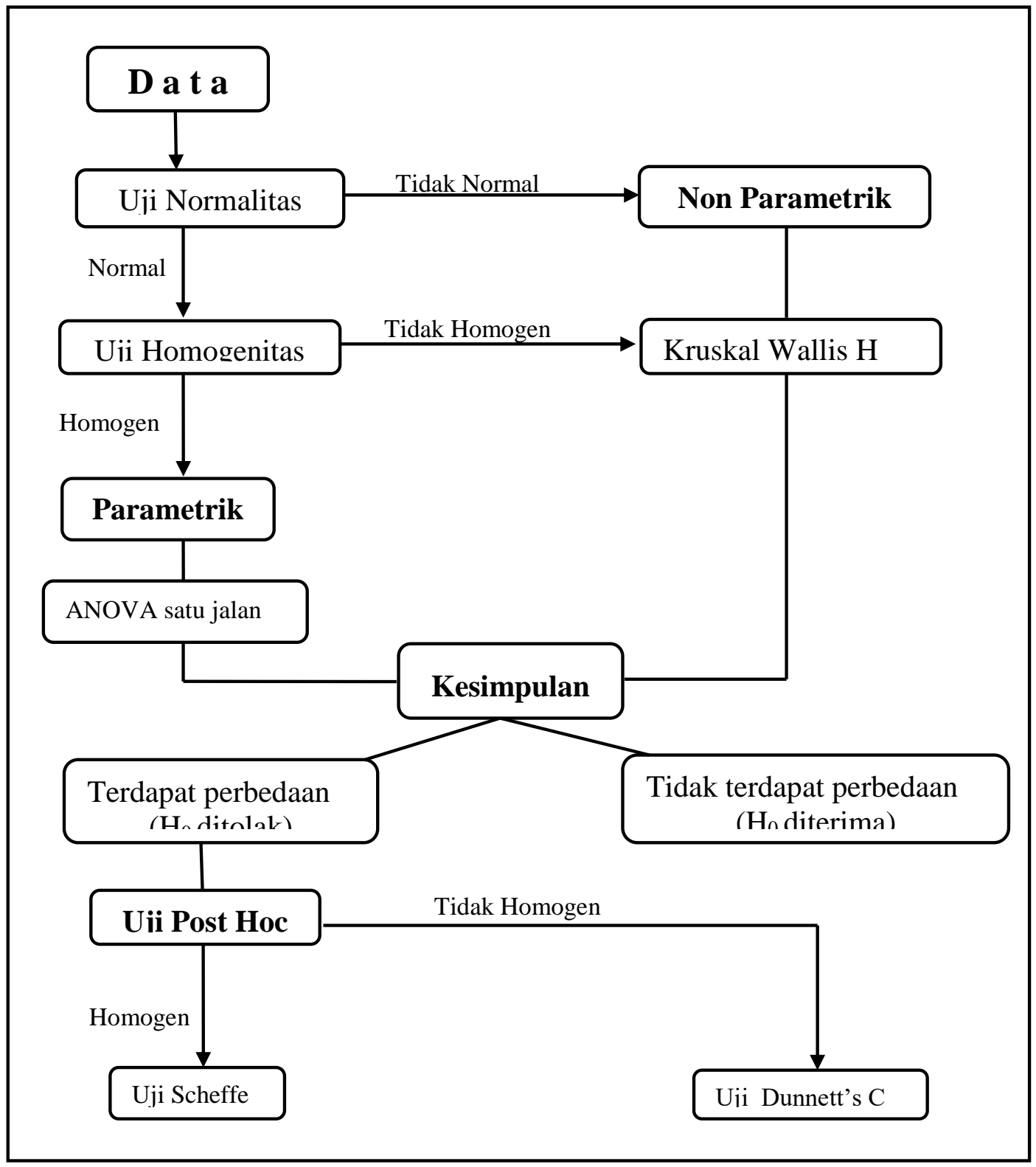

Gambar 1. Alur Teknik Analisis Data 


\section{Hasil dan Pembahasan}

\subsection{Gambaran Variabel}

Berikut ini gambaran kemampuan representasi matematis mahasiswa yang diperoleh dari hasil tes kemampuan representasi matematis mahasiswa pada mata kuliah Geometri Transformasi

Tabel 3. Statistik Deskriptif Kemampuan Representasi Matematis

\begin{tabular}{|c|c|c|c|c|c|c|}
\hline $\begin{array}{c}\text { Latar Belakang } \\
\text { Pendidikan } \\
\text { Menengah }\end{array}$ & $\mathrm{N}$ & $\mathrm{X}_{\min }$ & $\mathrm{X}_{\text {maks }}$ & Mean & Varians & $\mathrm{s}$ \\
\hline SMA-IPA & 60 & 3 & 87 & 67,57 & 201,877 & 14,208 \\
\hline SMA-IPS & 38 & 82 & 87 & 69,87 & 58,334 & 7,638 \\
\hline SMK & 33 & 0 & 64,09 & 64,09 & 210.648 & 14,514 \\
\hline MA & 28 & 0 & 84 & 66,25 & 262,565 & 16,204 \\
\hline
\end{tabular}

Berdasarkan data pada Tabel 3 di atas terlihat bahwa rerata skor pada masing-masing kelompok memiliki perbedaan yang kecil kecuali rerata pada kelompok latar belakang SMA-IPS berbeda cukup tinggi jika dibandingkan dengan kelompok yang lainnya. Begitu pun dengan nilai simpangan baku pada kelas yang berlatar belakang SMA-IPA, SMK, dan MA. Hal ini menunjukkan bahwa penyebaran skor ketiga kelompok tersebut sama beragam, kecuali kelompok SMA IPS. Guna melihat apakah perbedaan tersebut signifikan secara statistik, maka perlu dilakukan pengujian secara inferensial. Pengujian secara inferensial menggunakan statistik parametrik memerlukan terpenuhinya asumsi data berdistribusi normal dan variansi kelompok data homogen.

Uji normalitas dilakukan dengan bantuan software SPSS. Pengujian hipotesis dilakukan menggunakan statistik uji Kolmogorov-Smirnov dengan taraf signifikansi $(\alpha)$ sebesar $5 \%(0,05)$. Adapun output dari analisis uji normalitas ditunjukkan pada Tabel 4.

Tabel 4. Output Uji Normalitas Data Kemampuan Representasi Matematis Mahasiswa pada Mata Kuliah Geometri Transformasi

\begin{tabular}{|c|c|c|c|c|c|c|c|}
\hline \multirow{2}{*}{ Data } & \multirow{2}{*}{$\begin{array}{l}\text { Latar Belakang } \\
\text { Pendidikan } \\
\text { Menengah }\end{array}$} & \multicolumn{3}{|c|}{ Kolmogorov-Smirnova } & \multicolumn{3}{|c|}{ Shapiro-Wilk } \\
\hline & & $\begin{array}{c}\text { Statist } \\
\text { ic }\end{array}$ & Df & Sig. & Statistic & $\mathrm{df}$ & Sig. \\
\hline \multirow{4}{*}{$\begin{array}{l}\text { Nilai } \\
\text { Geometri } \\
\text { Transformas } \\
\text { i }\end{array}$} & SMA-IPA & .222 & 60 & .000 & .697 & 60 & .000 \\
\hline & SMA-IPS & .096 & 38 & $.200^{*}$ & .981 & 38 & .750 \\
\hline & \begin{tabular}{|l|} 
SMK \\
\end{tabular} & .222 & 33 & .000 & .740 & 33 & .000 \\
\hline & MA & .243 & 28 & .000 & .716 & 28 & .000 \\
\hline \multicolumn{8}{|c|}{ a. Lilliefors Significance Correction } \\
\hline \multicolumn{8}{|c|}{ *. This is a lower bound of the true significance. } \\
\hline
\end{tabular}

Berdasarkan Tabel 4 di atas, baik menggunakan Kolmogorof-Smirnov maupun Shapiro-Wilk diperoleh nilai signifikansi (p-value) untuk SMA-IPA, SMK, dan MA masing-masing sebesar 0,000 (kurang dari $\alpha$ ). Hal ini menunjukkan bahwa ketiga kelompok data tersebut berdistribusi normal. Sementara itu, hasil uji Kolmogorof-Smirnov pada data SMA-IPS diperoleh nilai signifikansi sebesar 0,200, sedangkan hasil uji Shapiro-Wilk diperoleh nilai signifikansi sebesar 0,750. Kedua nilai tersebut lebih besar jika dibandingkan dengan $\alpha=0,05$. Ini menunjukkan bahwa data SMAIPS tidak berdistribusi normal. Dikarenakan salah satu data tidak berdistribusi normal, maka pengujian secara inferensial selanjutnya dilakuka menggunakan statistik non-parametrik, yaitu menggunakan uji Kruskal-Walis $H$.

\subsection{Perbandingan Kemampuan Representasi Matematis}

Guna melihat apakah terdapat perbedaan kemampuan representasi matematis siswa masingmasing kelompok berdasarkan latar belakang pendidikan menengah, maka dilakukan uji perbedaan rerata kelompok sampel dengan unji Kruskal-Walis $H$. Pengujian dilakukan 
menggunakan bantuan software SPSS pada taraf signifikansi $\alpha=5 \%$. Output hasil perhitungannya ditunjukkan pada Tabel 5.

Tabel 5. Output Uji Kruskal-Wallis $H$

\begin{tabular}{|c|c|}
\hline \multicolumn{1}{|c|}{ Test Statistics } \\
\hline & $\begin{array}{c}\text { Nilai } \\
\text { Geometri } \\
\text { Transformasi }\end{array}$ \\
\hline Chi-Square & 5.047 \\
df & 3 \\
Asymp. Sig. & .168 \\
\hline a. Kruskal Wallis Test \\
b. Grouping Variable: Latar \\
Belakang Pendidikan Menengah
\end{tabular}

Berdasarkan Tabel 5 di atas, diperoleh nilai signifikansi untuk keempat kelompok sebesar 0,168. Nilai signifikansi yang lebih besar dari $\alpha=5 \%$, menujukkan penerimaan terhadap $H_{0}$. Dengan kata lain, tidak terdapat perbedaan yang signifikan secara statistik dalam hal kemampuan representasi matematis mahasiwa diantara keempat kelompok tersebut.

Berdasarkan hasil analisis data menunjukkan tidak terdapat perbedaan kemampuan representasi matematis mahasiswa berdasarkan latar belakang pendidikan menengah. Artinya latar belakang pendidikan menengah bukan faktor yang mempengaruhi kemampuan representasi matematis. Dengan demikian, tidak cukup bukti untuk mendukung dugaan peneliti yang semula. Hal tersebut mungkin saja dikarenakan mahasiswa yang mengontrak mata kuliah Geometri Transformasi sudah menempuh studi selama 5 semester, sehingga latar belakang pendidikan menengah tidak lagi menjadi faktor penentu dalam penguasaan kemampuan representasi matematis. Sebagaimana diketahui bahwa sebelum mengontrak mata kuliah Geometri Transformasi, mahasiswa semester 5 telah dibekali materi perkuliahan yang menuntut kemampuan representasi matematis seperti pada mata kuliah Kapita Selekta Geometri. Namun jika penelitian ini dilakukan pada mahasiswa semester 1, tidak menutup kemungkinan bahwa latar belakang pendidikan menengah dapat menjadi salah satu faktor penentu dalam penguasaan kemampuan representasi matematis mahasiswa.

\section{Simpulan}

Berdasarkan penelitian dapat disimpulkan bahwa tidak cukup bukti untuk menyatakan bahwa terdapat perbedaan kemampuan representasi matematis mahasiswa pada mata kuliah Geometri Transformasi berdasarkan latar belakang pendidikan menengah.

\section{Daftar Pustaka}

1. Fraenkel, J.R., Wallen, N.E., and Hyun, H.H. 2012. How to Design and Evaluate Research in Education. United States (New York): McGraw-Hill Companies., Inc.

2. Gagatsis, A., and Elia, I. 2004. "The Effects of Different Modes of Representation on Mathematical Problem Solving". Proceedings of the 28th Conference of the International Group for the Psychology of Mathematics Education. 2(2), 447-454.

3. Guler, G., and Ciltas, A. 2011. "The Visual Representation Usage Levels of Mathematics Teachers and Students in Solving Verbal Problems". International Journal of Humanities and Social Science. 1(11), 145-154.

4. Kerlinger, F. N. and Elazar J. P. 1973. Multiple Regression in Behavioral Research. New York: Rinehaert and Winstion, Inc. 
5. Lestari, K. E dan Yudhanegara, M.R. 2015. Penelitian Pendidikan Matematika. Bandung: Refika Aditama.

6. Rawuh. 1993. Geometri Transformasi. Jakarta: Departemen Pendidikan dan Kebudayaan Direktorat Jenderal Pendidikan Tinggi 